\title{
Yield ability of winter wheat depending on fertilizer system in different crop rotations of Forest-steppe
}

\author{
S. Bondar \\ Institute of Bioenergy Crops and Sugar Beet NAAS
}

The purpose. To justify productivity of winter wheat in different crop rotations depending on fertilizer system and saturation of crop rotation by tilling and cereal crops. Methods. Field, analytical, statistical. Results. Influence of crop rotations on productivity of winter wheat depending on fertilizer system, level of biologization of crop rotations and climatic features of years is investigated. Conclusions. On prosperous backgrounds of fertilizing in a link with vetch-oats productivity of winter wheat did not depend on availability of tilling and cereal crops. So on the background of N60P60K60 it made 4,97 $-5,10 \mathrm{t} /$ hectare . Ploughing of crop residues in field crop rotation + N60P60K60 by its effect on productivity does not yield to organic-mineral background of fertilizing. Increase of temperature of air during vegetation of winter wheat reduces its productivity for $3,78-3,35$ t/hectare. Optimum air temperatures at sufficient moistening secures increase of yield for $1,60-1,96 \mathrm{t} /$ hectare.

Key words: winter wheat, fertilizer

Winter wheat is one of the leading crops in rotation and the main forecrop of sugar beet and corn for grain. The yield of this crop under the conditions of Forest-Steppe zone can be affected by soil moisture, crop rotations and availability of nutrients in the soil. The most significant effect on winter wheat yield is done by the interval in crop rotation.

The yield of winter wheat may also be affected by its varietal characteristics, soil and climatic conditions, fertilization practice and optimization of mineral nutrition.

The optimal share of wheat in crop rotation within the boundary of subzone sufficient moisture is 20 $30 \%$. Increasing the share to $40 \%$ promotes grain yield, but may reduce the yield of aftercrops in the rotation and reduce the gross grain yield on a particular farm. The shortest interval that does not reduce yield is two years $[6,11]$.

The practice of fertilization has a significant effect on yield of winter wheat because it is fast affecting factor increasing the yield of winter wheat and improving grain quality $[2,11,12,13]$.

Growing winter wheat against the aftereffect of organic fertilizers makes it possible to reduce the application dose of fertilizer and improve the quality of grain $[6,11]$.

Of special relevance is the question of doses and methods of the application taking into account the biological characteristics of novel winter wheat varieties. [12]. The issue of optimizing nitrogen supply is of particular importance in the process of improving fertilization practice. The results of numerous studies in different regions of Ukraine show that to produce high yields of winter wheat it is recommended to introduce at least $90-120 \mathrm{~kg} / \mathrm{ha}$ of active ingredients of nitrogen, phosphorus, and potassium. [6,11].

The efficiency of fertilizers depends on the provision of soil with nutrients, forecrop, and features of a variety [10].

Under the conditions of unstable soil moisture (for leached typical black soil), the best forecrops for winter wheat are the following: grasses, pea, and vetch \& oat as mix crops. According to Ivanina [6], the yield of winter wheat in the link after pea against the background without fertilizers was $4.51 \mathrm{t} / \mathrm{ha}$, after vetch \& oat $4.01 \mathrm{t} / \mathrm{ha}$, while after clover it was 2.85 , maize for silage 3.87 , and oil radish $3,57 \mathrm{t} / \mathrm{ha}$.

In varying crop rotation, when growing winter wheat after esparcet \& Festuca pratensis mix crops, grain yield was $5.11 \mathrm{t} / \mathrm{ha}$, after corn for silage $4.59 \mathrm{t} / \mathrm{ha}$, after fallow $6.04 \mathrm{t} / \mathrm{ha}$, pea $4.85 \mathrm{t} / \mathrm{ha}$, and winter 
wheat 4.14 t/ha [11]. Overall, the yield of winter wheat depends on the rotation links, fertilization practice and soil fertility.

\section{Purpose}

To substantiate the yield of winter wheat in different crop rotations as affected by various fertilization practices and share of grain and row crops in crop rotation.

\section{Materials and methods}

The studies were carried out as a stationary field experiment at the Bila Tserkva Research Breeding Station from 2013 to 2015.

The soil of research field was leached typical black soil with the following agrochemical indexes: humus in $0-30 \mathrm{~cm}$ layer (by Turin) 3.6-4.1\%, mobile phosphorus and exchangeable potassium (by Chirikov) $200-70 \mathrm{mg} / \mathrm{kg}$, alkali hydrolyzed nitrogen (by Kornfeld) $120-140 \mathrm{mg} / \mathrm{kg}$.

The studies were conducted in six-link crop rotation. Varying crop rotations consisted of the following crops:

i. crop rotation: fodder crops $33 \%, 17 \%$ row crops, grain crops $50 \%$ (vetch \& oat - winter wheat sugar beet - barley \& clover - clover - winter wheat);

ii. row crop rotation: fodder crops $17 \%$, row crops $50 \%$, grains $33 \%$ (vetch \& oat - winter wheat sugar beet - barley - soya - sunflower);

iii. grain - row crop rotation: fodder crops $17 \%$, row crops $33 \%$, grain crops $50 \%$ (vetch \& oat - winter wheat - sugar beet - barley - rape - winter wheat).

The design of crop rotation and fertilization is shown in Table 1.

Winter wheat was seeded after vetch \& oat, for which three-year data of the second rotation was obtained. The technology of growing winter wheat was typical for the area. Winter wheat variety "Vidrada".

The application rates of fertilizers per 1 ha of crop rotation area were following: $\mathrm{N}_{43} \mathrm{P}_{43} \mathrm{~K}_{43}$ and organic 8.3 t. Mineral fertilizers were introduced under all the crops except the links with vetch \& oat and barley. Residues of all crops were ploughed into the soil according to experiment design.

In the experiment, we used conventional methods and recommendations [3].

\section{Results}

The studies have shown that the yield of winter wheat depended on the dose of fertilizer, weather patterns, and crop rotations.

Thus, in crop rotation against the background of $8.3 \mathrm{t} / \mathrm{ha}+\mathrm{N}_{43} \mathrm{P}_{43} \mathrm{~K}_{43}$ per rotation and $\mathrm{N}_{60} \mathrm{P}_{60} \mathrm{~K}_{60}$ directly under the winter wheat yield was $4.97 \mathrm{t} / \mathrm{ha}$, in row crop rotation $5.10 \mathrm{t} / \mathrm{ha}$, grain - row crop rotation 4.87 $\mathrm{t} / \mathrm{ha}$. The decline of yield in crop rotation by $0.13 \mathrm{t} / \mathrm{ha}$ compared to grain - row crop rotation was due to the cultivation interval one year (Table 1).

In the treatment where crop residues of all crops were utilized $+\mathrm{N}_{60} \mathrm{P}_{60} \mathrm{~K}_{60}$ directly under winter wheat, the yield was $5.0 \mathrm{t} / \mathrm{ha}$, which was at the level of organic-mineral fertilizer system. Introducing only mineral fertilizers decreased grain yield by $0.23 \mathrm{t} / \mathrm{ha}$ according to the organic and mineral background, and grain yield does not exceed $4.87 \mathrm{t} / \mathrm{ha}$.

Fertilization practice applied in crop rotation, in particular, the link of winter wheat generally has a significant impact on the yield $[6,11]$. Thus, in grain - row crop rotation, by reducing the dose of fertilizer to $\mathrm{N}_{60} \mathrm{P}_{30} \mathrm{~K}_{60}$ and $\mathrm{N}_{60} \mathrm{P}_{30} \mathrm{~K}_{30}$ winter wheat yield was 4.62 and $4.67 \mathrm{t} / \mathrm{ha}$, respectively, which was less than when applying a full dose of fertilizer by 0.48 and $0.47 \mathrm{t} /$ ha, respectively (Table 2). With the exception of phosphorus from the of mineral nutrition system wheat yield was inferior to the treatment with a full dose of fertilizer by $0.68 \mathrm{t} / \mathrm{ha}$ and made up $4.42 \mathrm{t} / \mathrm{ha}$. This reduction in yield was due to black soil specifics, i.e. good response of black soil to the application of phosphate fertilizers, while application of manure is unable to meet the demand for phosphorus supply.

Thus, introduction of phosphate fertilizers in the mineral nutrition system for winter wheat contributes to obtaining high grain yield even against the background of organic and mineral fertilization in crop rotation. Increasing the application dose of fertilizer to $\mathrm{N}_{80} \mathrm{P}_{100} \mathrm{~K}_{100}$ and $\mathrm{N}_{90} \mathrm{P}_{60} \mathrm{~K}_{60}$ ensured grain yield of 5.23 and $5.18 \mathrm{t} / \mathrm{ha}$, respectively, which was at the level of the $\mathrm{N}_{60} \mathrm{P}_{60} \mathrm{~K}_{60}$ treatment. This low efficiency of 
the above-mentioned doses of mineral fertilizers was due to the aftereffect of manure applied in the rotation, which reduces their effectiveness.

Table 1. Yields of winter wheat as affected by crop rotation and fertilization practice (t/ha) 20132015, BTsRBS

\begin{tabular}{|c|c|c|c|c|c|}
\hline \multirow{2}{*}{ No. } & \multirow[b]{2}{*}{ Treatment } & \multicolumn{4}{|c|}{ Grain yield (t/ha) } \\
\hline & & 2013 & 2014 & 2015 & $\begin{array}{l}\text { Average of 2013- } \\
2015\end{array}$ \\
\hline \multicolumn{6}{|c|}{ Crop rotation (clover, wheat, winter wheat, vetch \& oat, winter wheat) } \\
\hline 1 & No fertilization since 1976 & 1.86 & 4.56 & 5.65 & 4.02 \\
\hline \multirow{2}{*}{2} & $\mathrm{~N}_{43.3} \mathrm{P}_{43.3} \mathrm{~K}_{43.3}+$ stubble* & \multirow{2}{*}{3.29} & \multirow{2}{*}{4.93} & \multirow{2}{*}{6.77} & \multirow{2}{*}{5.00} \\
\hline & $\mathrm{N}_{60} \mathrm{P}_{60} \mathrm{~K}_{60}{ }^{\text {*k }}$ & & & & \\
\hline \multirow{2}{*}{3} & $\mathrm{~N}_{43.3} \mathrm{P}_{43.3} \mathrm{~K}_{43.3}+8.3 \mathrm{t} /$ ha manure ${ }^{*}$ & \multirow{2}{*}{3.15} & \multirow{2}{*}{4.84} & \multirow{2}{*}{6.93} & \multirow{2}{*}{4.97} \\
\hline & $\mathrm{N}_{60} \mathrm{P}_{60} \mathrm{~K}_{60}{ }^{* *}$ & & & & \\
\hline \multicolumn{6}{|c|}{ Row crop rotation (soya, sunflower, vetch \& oat, winter wheat) } \\
\hline 4 & No fertilization since 1976 & 2.08 & 4.61 & 5.52 & 4.07 \\
\hline \multirow{2}{*}{5} & $\mathrm{~N}_{43.3} \mathrm{P}_{43.3} \mathrm{~K}_{43.3}+8.3$ t/ha manure ${ }^{*}$ & \multirow{2}{*}{3.21} & \multirow{2}{*}{5.28} & \multirow{2}{*}{6.82} & \multirow{2}{*}{510} \\
\hline & $\mathrm{N}_{60} \mathrm{P}_{60} \mathrm{~K}_{60}{ }^{*}$ & & & & \\
\hline \multicolumn{6}{|c|}{ Grain - row crop rotation (rape, winter wheat, vetch \& oat, winter wheat) } \\
\hline 6 & No fertilization since 1976 & 2.17 & 4.67 & 5.49 & 4.11 \\
\hline \multirow{2}{*}{7} & $\mathrm{~N}_{43.3} \mathrm{P}_{43.3} \mathrm{~K}_{43.3}+8.3$ t/ha manure ${ }^{*}$ & \multirow{2}{*}{3.31} & \multirow{2}{*}{5.29} & \multirow{2}{*}{6.70} & \multirow{2}{*}{5.10} \\
\hline & $\mathrm{N}_{60} \mathrm{P}_{60} \mathrm{~K}_{60}{ }^{*}$ & & & & \\
\hline \multirow{2}{*}{8} & $\mathrm{~N}_{43.3} \mathrm{P}_{43.3} \mathrm{~K}_{43.3} *$ & \multirow{2}{*}{3.09} & \multirow{2}{*}{5.07} & \multirow{2}{*}{6.44} & \multirow{2}{*}{4.87} \\
\hline & $\mathrm{N}_{60} \mathrm{P}_{60} \mathrm{~K}_{60}{ }^{* *}$ & & & & \\
\hline \multicolumn{2}{|c|}{$\mathrm{LSD}_{05}$} & 0.18 & 0.22 & 0.31 & 0.25 \\
\hline
\end{tabular}

${ }^{*}$ fertilization practice in rotation; ${ }^{*}$ fertilization practice in winter wheat

Weather conditions had a significant impact on the crop productivity. In 2013, high temperature was observed in May, up to $18.5^{\circ} \mathrm{C}$, and in June, up to $+20.7^{\circ} \mathrm{C}$, with average long-term data of $+14.9{ }^{\circ} \mathrm{C}$ and $+17.8^{\circ} \mathrm{C}$, respectively, supplemented by optimal precipitation in May $(79.5 \mathrm{~mm})$, and in June $(98.6$ $\mathrm{mm}$ ), which exceeded long-term data by 33.50 and $25.60 \mathrm{~mm}$, respectively. To illustrate, in crop rotation fertilized with mineral fertilizer $\left(\mathrm{N}_{60} \mathrm{P}_{60} \mathrm{~K}_{60}\right.$ for winter wheat) against the background of stubble residues aftereffect, grain yield was $3.29 \mathrm{t} / \mathrm{ha}$, and in the treatment with manure application as the background $3.15 \mathrm{t} / \mathrm{ha}$, which was higher if compared to background without fertilizers by 1.43 and $1.29 \mathrm{t} / \mathrm{ha}$. In grainrow crop rotation against the background of mineral fertilizer, grain yield was $3.09 \mathrm{t} / \mathrm{ha}$, which was inferior to organic and mineral fertilization practice by $0.22 \mathrm{t} /$ ha (Table 2 ).

Table 2. Yield of winter wheat in grain-row rotation as affected by fertilization practice $(t / h a) 2013-$ 2016, BTsRBS

\begin{tabular}{|l|l|l|l|l|l|}
\hline \multirow{2}{*}{ No. } & Treatment & Grain yield (t/ha) & $\mathbf{2 0 1 5}$ & $\begin{array}{l}\text { Average of } \\
\mathbf{2 0 1 3 - 2 0 1 6}\end{array}$ \\
\cline { 2 - 6 } & $\mathbf{2 0 1 3}$ & $\mathbf{2 0 1 4}$ & 5.49 & 4.11 \\
\hline 1 & No fertilization & 2.17 & 4.67 & & \\
\hline 2 & $\begin{array}{l}8.3 \mathrm{t} / \mathrm{ha} \mathrm{manure}+ \\
\mathrm{N}_{43.3} \mathrm{P}_{21.6} \mathrm{~K}_{21.6} *\end{array}$ & & & 4.62 \\
\cline { 2 - 5 } & $\mathrm{N}_{60} \mathrm{P}_{30} \mathrm{~K}_{30} * *$ & 4.75 & 6.14 & 4.68 \\
\hline
\end{tabular}




\begin{tabular}{|c|c|c|c|c|c|}
\hline \multirow[t]{2}{*}{3} & $\begin{array}{l}8.3 \text { t/ha manure }+ \\
\mathrm{N}_{43.3} \mathrm{P}_{21.6} \mathrm{~K}_{43.3} *\end{array}$ & \multirow[b]{2}{*}{2.86} & \multirow[b]{2}{*}{4.85} & \multirow[b]{2}{*}{6.31} & \multirow[b]{2}{*}{4.67} \\
\hline & $\mathrm{N}_{60} \mathrm{P}_{30} \mathrm{~K}_{60}{ }^{\text {** }}$ & & & & \\
\hline \multirow[t]{2}{*}{4} & $\begin{array}{l}8.3 \text { t/ha manure + } \\
\mathrm{N}_{43.3} \mathrm{P}_{0} \mathrm{~K}_{43.3} *\end{array}$ & \multirow[b]{2}{*}{2.59} & \multirow[b]{2}{*}{4.74} & \multirow[b]{2}{*}{5.94} & \multirow[b]{2}{*}{4.42} \\
\hline & $\mathrm{N}_{60} \mathrm{P}_{0} \mathrm{~K}_{60}{ }^{* *}$ & & & & \\
\hline \multirow[t]{2}{*}{5} & $\begin{array}{l}8.3 \text { t/ha manure + } \\
\mathrm{N}_{65} \mathrm{P}_{85} \mathrm{~K}_{85} *\end{array}$ & \multirow[b]{2}{*}{3.69} & \multirow[b]{2}{*}{4.96} & \multirow[b]{2}{*}{7.04} & \multirow[b]{2}{*}{5.23} \\
\hline & $\mathrm{N}_{80} \mathrm{P}_{100} \mathrm{~K}_{100}{ }^{* *}$ & & & & \\
\hline \multirow[t]{2}{*}{6} & $\begin{array}{l}8.3 \text { t/ha manure }+ \\
\mathrm{N}_{65} \mathrm{P}_{43.3} \mathrm{~K}_{43.3} *\end{array}$ & \multirow[b]{2}{*}{3.53} & \multirow[b]{2}{*}{5.07} & \multirow[b]{2}{*}{6.95} & \multirow[b]{2}{*}{5.18} \\
\hline & $\mathrm{N}_{90} \mathrm{P}_{60} \mathrm{~K}_{60}$ ** & & & & \\
\hline \multirow[t]{2}{*}{7} & $\begin{array}{l}8.3 \text { t/ha manure }+ \\
\mathrm{N}_{43,}, \mathrm{P}_{43.3} \mathrm{~K}_{65}{ }^{*}\end{array}$ & \multirow[b]{2}{*}{3.44} & \multirow[b]{2}{*}{5.31} & \multirow[b]{2}{*}{6.67} & \multirow[b]{2}{*}{5.14} \\
\hline & $\mathrm{N}_{60} \mathrm{P}_{60} \mathrm{~K}_{90}{ }^{\text {** }}$ & & & & \\
\hline \multirow[t]{2}{*}{8} & $\begin{array}{l}8.3 \text { t/ha manure + } \\
\mathrm{N}_{43.3} \mathrm{P}_{43.3} \mathrm{~K}_{43.3} *\end{array}$ & \multirow[t]{2}{*}{3.31} & \multirow[t]{2}{*}{5.29} & \multirow[t]{2}{*}{6.70} & \multirow[t]{2}{*}{5.10} \\
\hline & $\mathrm{N}_{60} \mathrm{P}_{60} \mathrm{~K}_{60}{ }^{* *}$ & & & & \\
\hline \multirow[t]{3}{*}{9} & $\mathrm{~N}_{43.3} \mathrm{P}_{43.3} \mathrm{~K}_{43.3} *$ & \multirow{2}{*}{3.09} & \multirow{2}{*}{5.07} & \multirow{2}{*}{6.44} & \multirow{2}{*}{4.87} \\
\hline & $\mathrm{N}_{60} \mathrm{P}_{60} \mathrm{~K}_{60}{ }^{* *}$ & & & & \\
\hline & $\mathrm{LSD}_{05}$ & 0.18 & 0.25 & 0.28 & 0.25 \\
\hline
\end{tabular}

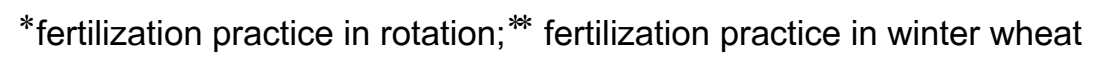

In grain-row crop rotation, by reducing the application rate of phosphorus and potassium the yield obtained was 2.98 and $2.88 \mathrm{t} / \mathrm{ha}$, whereas by the exception of phosphorus it was $2.59 \mathrm{t} / \mathrm{ha}$, which was inferior to application of full dose of fertilizer by $0.45,0.72$, and 0.71 (treatments 3,4 , and 5 , Table 2 ). In the treatment with a high dose of $\mathrm{N}_{80} \mathrm{P}_{100} \mathrm{~K}_{100}$ and $\mathrm{N}_{90} \mathrm{P}_{60} \mathrm{~K}_{60}$, grain yield was 3.69 and $3.54 \mathrm{t} / \mathrm{ha}$, which exceeded the treatment with the introduction of $\mathrm{N}_{60} \mathrm{P}_{60} \mathrm{~K}_{60}$ solely by 0.38 and $0.22 \mathrm{t} / \mathrm{ha}$, respectively. Therefore, in less favourable years, high doses of fertilizers are not effective, due to insufficient transfer of nutrients in the soil solution and their utilization by plants.

Under the conditions of 2015 winter wheat yield was very high. The temperature was more favourable for plant growth and development. The average temperature in April was $+9.3^{\circ} \mathrm{C}, 16.3^{\circ} \mathrm{C}$ in May, and $19.6{ }^{\circ} \mathrm{C}$ in June, while the average long-term temperature was $+8.4{ }^{\circ} \mathrm{C},+14.9{ }^{\circ} \mathrm{C}$, and $+17.8{ }^{\circ} \mathrm{C}$, respectively. Rainfall in April, May, and June reached 12.5, 32.2, and $28.7 \mathrm{~mm}$, while long-term values were $47.0,46.0$, and $73 \mathrm{~mm}$, respectively. In crop rotation against the background of $8.3 \mathrm{t} / \mathrm{ha}$ manure + $\mathrm{N}_{43} \mathrm{P}_{43} \mathrm{~K}_{43}$ and introduction of $\mathrm{N}_{60} \mathrm{P}_{60} \mathrm{~K}_{60}$ directly under winter wheat, grain yield was $6.93 \mathrm{t} /$ ha, while in row crop rotation it was 6.82 and in gran-row crop rotation 6.70 t/ha. In the crop rotation where stubble residues were ploughed into the soil, grain yield was $6.77 \mathrm{t} / \mathrm{ha}$, which corresponded to the yield at organic-mineral fertilization. Introduction of mineral fertilizers only in grain-row crop rotation ensured winter wheat yield of $6.44 \mathrm{t} / \mathrm{ha}$.

The highest grain yield in row crop rotation $(7.04 \mathrm{t} / \mathrm{ha})$ was obtained by introduction of $\mathrm{N}_{80} \mathrm{P}_{100} \mathrm{~K}_{100}$, which exceeded the yield in the treatment with introduction of $\mathrm{N}_{60} \mathrm{P}_{60} \mathrm{~K}_{60}$ by $0.34 \mathrm{t} /$ ha and the treatment with the background without fertilizer by 1.55 t/ha. Reducing the dose of fertilizer to $\mathrm{N}_{60} \mathrm{P}_{30} \mathrm{~K}_{30}$ and $\mathrm{N}_{60} \mathrm{P}_{60} \mathrm{~K}_{60}$ decreased yield by 0.56 and 0.39 t/ha, respectively, as compared with introduction of $\mathrm{N}_{60} \mathrm{P}_{60} \mathrm{~K}_{60}$.

Thus, utilization of stubble residues in all crop rotations against the background of mineral fertilization is not inferior to yield at organic and mineral fertilization. 


\section{Conclusions}

1. In the link with vetch \& oat, winter wheat yield is not affected by the presence of row and grain crops against highly provided fertilization backgrounds. In particular, grain yield was 4.97 to $5.10 \mathrm{t} / \mathrm{ha}$ against the background of $\mathrm{N}_{60} \mathrm{P}_{60} \mathrm{~K}_{60}$. Ploughing stubble residues into the soil in crop rotation $+\mathrm{N}_{60} \mathrm{P}_{60} \mathrm{~K}_{60}$ is not inferior to organic and mineral fertilizer background in terms of the effect on yield.

2. High application rate of fertilizer $\mathrm{N}_{80} \mathrm{P}_{100} \mathrm{~K}_{100}$ introduced against the aftereffect of organic and mineral fertilizer background is ineffective.

3. Mineral nutrition of winter wheat reduces its yield by $0.23 \mathrm{t} / \mathrm{ha}$.

4. High temperature during the growing season significantly reduces winter wheat productivity by $3.78-$ $3.355 \mathrm{t} / \mathrm{ha}$, while optimal temperature along with sufficient moisture ensures boost yield by $1.60-1.96 \mathrm{t} / \mathrm{ha}$.

\section{Bibliography's}

1. Galychenko, I.I. (2012). Yield of winter wheat as affected by preceding crop. Zemledelie [Farming], 1, 35-36. [in Russian]

2. Horodnii, M.M. \& Motrynchuk, D. Yo. (2008). Effect of foliar feeding with new fertilizers on yield and quality of new intense winter wheat varieties on dark grey-ashed soils. Basics of crop productivity formation at intensive cultivation technologies. Kyiv. [in Ukrainian]

3. Dospehov, B.A. (1985). The method of field experience (with basics of statistical processing of research data). Moscow: Agropromizdat. [in Russian]

4. Zarishnyak, A.S., Rutskaya, T.V. \& Kalibabchuk, T.V. (2003). Effect of regular introduction of fertilizers in grain - beet rotation on crop productivity in the Central Forest-Steppe zone of Right Bank of Ukraine. Agrohimiya [Agricultural chemistry], 6, 30-36. [in Russian]

5. Yefremov, V.F., Kurmysheva, N.A, \&Trofimova, \& N. P. (1992), Effect of fertilization practices and crop rotations on mineral nitrogen dynamics in soil and winter wheat grain quality. Agrohimiya [Agricultural chemistry], 7, 63-67. [in Russian]

6. Ivanina, V.V. (2016). Biologization of fertilizing crops in crop rotations. Kyiv: Komprynt. [in Ukrainian]

7. V. Lykhochvor, Petrenko, V.F. \&. Ivashchuk, P.V. (2008). Grain production. Lviv: Ukrainian technologies. [in Ukrainian]

8. Meneev, V.G. (1973). Fertilization of winter wheat. Moscow: Kolos. [in Russian]

9. Saiko, V. F., Svydyniuk, I.M. \& Kononiuk, L.M. (2009). Technology of high-quality winter wheat in the Forest-Steppe and Polissia of Ukraine. Manual of grain producer, 45-48. [in Ukrainian]

10. Slobodian, S.M. (1995). Growth and formation of crop productivity and quality of grain-beet crop rotation when applying calculated fertilizers rates in the south-western part of Forest-Steppe of Ukraine: Author. Doctoral Dis. Kyiv. [in Ukrainian]

11. Tsvei, Ya.P. (2014). Soil fertility and productivity of crop rotation. Kyiv: Komprynt. [in Ukrainian] 